\title{
'Keeping head above water': A case study in religious leadership in a polluted context
}

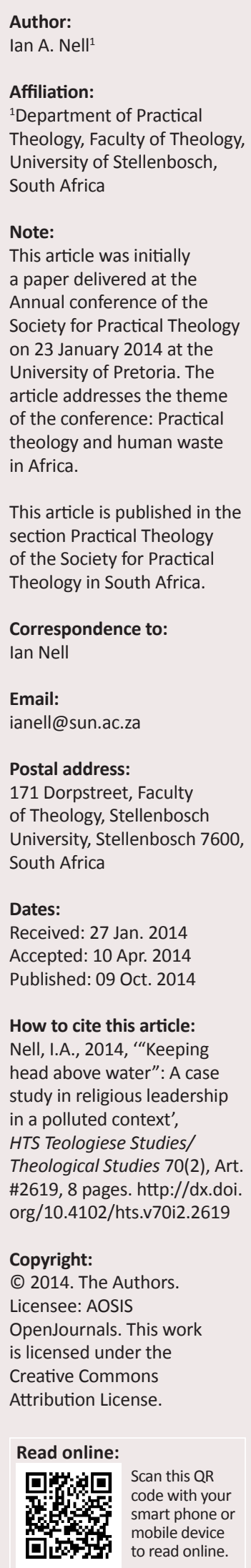

'We must stop wasting our precious water - and also stop polluting it.' These are the words of Dr Jo Barnes, Epidemiologist and Senior Lecturer in Community Health at the University of Stellenbosch's Faculty for Health Sciences. Her research involves the quality of water in rivers and its health impact on communities. It is general knowledge that health services are struggling under the burden of diseases resulting from environmental pollution, particularly water pollution. This potentially avoidable crisis is slowly turning into a disaster. The article draws on a case study done in the informal settlement of Sweet Home Farm in Philippi, Cape Town, with the intent of compiling a descriptive empirical report on the way the community deals with human waste. In a next step, interpretive lenses are used to look with 'deeper understanding' at the problem of human waste and pollution. After that, the focus shifts to the problem of a theology of human waste, and the article concludes with suggestions on the role of religious leadership and ways in which leaders can play a constructive role in handling the crisis of a polluted context.

Toilets in the modern water closets rise up from the floor like water lilies. The architect does all he can to make the body forget how paltry it is and to make man ignore what happens to his intestinal wastes after the water from the tank flushes them down the drain ... Spontaneously, without any theological training, I, as a child, grasped the incompatibility of God and shit and thus came to question the basic thesis of Christian anthropology, namely that man was created in God's image. Either/or: either man was created in God's image - and has intestines! - or God lacks intestines and man is not like him. (Milan Kundera, The unbearable lightness of being 1984:132)

Water is life, sanitation is dignity. (City of Cape Town, n.d., 'Water and sanitation services standard', Preliminary draft 2, March 2008)

\section{Introduction}

United Nations documentation regarding access to sanitation facilities reports that 1.1 billion people worldwide practise 'public defecation'. ${ }^{1}$ Furthermore, Eye Witness News reports that, according to the World Health Organization (WHO), every 15 seconds a child dies from diarrhoea due to a lack of decent toilet amenities (Fisher 2012). Whilst on tour with fellow poets from Africa, Antjie Krog describes an incident in the town of Bamako in Mali. She relates her experience in the third person:

\begin{abstract}
She tries to go for a walk ... she hears a noise above her and stands aside just in time to avoid a slag of excrement that comes splattering down into the street from a kind of gutter overhead. How is it possible that people can produce such sophisticated architecture, such beautiful lines, let such colours bloom beneath their hands, yet are unable to deal effectively with their own excreta? And all of this beside one of the largest rivers in the world. In Bamako, even the sewers from the colonial era are still there, Somebody, for God's sake, just have to lift the sluice gate to wash away the rubbish and the sewage; but no, everything is left in the streets, the street along which the most beautifully decorated women are passing, sparkling with loveliness, calmly raising the hems of their robes and carefully stepping in their golden sandals around piles of human pellets. (Krog 2003:310)
\end{abstract}

The above-mentioned statistics and travel writings similar to that of Antjie Krog focuses one's attention on the enormous challenges we face in Africa as far as the management of human waste, here in the form of physical excrement, is concerned. The challenge of human waste could be described as a 'wicked problem', an expression often used by the public theologian William Storrar ${ }^{2}$ when referring to problems that have no easy solutions and that defy simplistic answers.

It is almost impossible to get proper insight into the extent of the problem of poor sanitation facilities without investigating conditions at grassroots level in a specific community. Therefore this study will look at one particular residential area - an informal settlement on the Cape Flats,

1.United Nations (UN) documents (2002).

2.Cf. Storrar (2013), who adopts the concept 'wicked problem' from social scientists who use it regularly. 
ironically named 'Sweet Home Farm'. After reading a newspaper article describing the appalling living conditions of the large number of residents, I decided to concentrate on this community. In my search for information about the wider context and circumstances of the people living there, I came across a memorandum researched and prepared by Jared Sacks (2012), a social-justice activist who clearly describes the challenges facing the population of Sweet Home Farm. His case study can be regarded as representative of thousands of similar poor communities all over South Africa and the rest of the continent. Keeping in mind that sanitation and the proper management of waste disposal is a basic socioeconomic right, ${ }^{3}$ it is understandable that, if there is mismanagement in this regard, heavy disputes will ensue, particularly in informal settlements.

The present study relates to the broader theme of the annual conference of the Society for Practical Theology, held in Pretoria on 22-24 January 2014, namely 'Practical theology and human waste in Africa'. The question it seeks to answer is: What can we learn about the management of human waste from a case study like the one on Sweet Home Farm? Furthermore, what role should leaders play to help people to, figuratively, 'keep head above water'? (with 'water' here referring to open sewage canals in informal settlements!).

The research method that was used in this study is that of a typical practical-theological study where, firstly, empirical observation is done, chiefly based on a case study. After this, underlying motifs of the situation as described come under scrutiny. In the last two phases, the researcher develops a theological perspective on the problem and, finally, tries to ascertain whether the intervention of leadership can help to resolve the situation.

\section{Sweet Home Farm - a case in point}

Sweet Home Farm is an informal settlement in Philippi on the Cape Flats that originated about 20 years ago due to the lack of housing in the metropolitan area (Sacks 2012:4). From the start, there was an enormous growth in the number of residents with numbers doubling in the past 10 years. Approximately 17000 people are now living in approximately 4000 informal constructions. The area (or 'ward') in question currently falls under the leadership of African National Congress (ANC) councillor Thembinkosi Pupa.

The way in which the community developed provides insight into the larger context of the challenges these people face. The land on which the community established themselves only recently became the property of the City of Cape Town. Up to the end of December 2011, Sweet Home Investments CC were the private owners of one-third of the property on which the settlement is situated. About half of the structures had been erected on this piece of land. The reason why no infrastructure was developed is because Sweet Home Investments CC refused any such development. However,

3.The General Meeting of the United Nations and the Committee on Human Rights in 2010 adopted a resolution: 'The human right to water and sanitation' (64/292) UN Documents (2002). no legal action was ever instituted to enforce basic services for the community. Sacks (2012:4) mentions the affiliation of Sweet Home Investments CC with the ANC as one of the important reasons for the lack of community participation in infrastructure development.

Notwithstanding inadequate basic services, the community has a strong sense of self-agency which can be observed in their self-implemented 'anti shack-fire strategy' as well as a number of informal community services sponsored by nongovernmental organisations (NGOs) and churches. These include the building and maintenance of a community hall and a non-profit crèche. At the same time, Sacks's (2012:5-7) report on Sweet Home Farm points out the lack of infrastructure in terms of electricity and water supply, formal housing, easily accessible health and education services and - in particular - the extremely poor condition of the area's sewer system.

In this regard, two specific problems can be singled out. Firstly, the public toilets in Sweet Home Farm are in a shocking state. The residents use a combination of flush, chemical and bucket-system toilets. Because a total of only 607 toilets have to be shared by about 17000 people, they are extremely messy, resulting in most of them being blocked or otherwise broken (Sacks 2012:7). The second problem, linked to the first, is that there are no underground drainpipes in the area but only open-air sewage canals running through the length of the residential area. This poses a severe health hazard because these canals get blocked very easily, and the sewage overflows right up to, and sometimes into, the residents' homes (Sacks 2012:7).

Obviously the informal dwellers of Sweet Home Farm are very unhappy about the deficient sewage system in their area. They dislike having to use public toilets, and when sewage water overflows into the streets, residents and children have to walk in or through it. When the sewage runs right into their homes, people have to clean it out manually, and it is difficult to rid the house of the bad odour. As a further result of these poor conditions, people residing in Sweet Home are marginalised by their friends and employers living in other communities because they are said to be 'filthy'. ${ }^{4}$

The situation regarding human waste is not only unpleasant but also life-threatening. The health risk is especially high for the very young and the elderly who get sick more easily (Sacks 2012:8). It is well known that, worldwide, about two million children die every year as a result of diarrhoea associated with bad sanitation (WaterAid 2013). Nevertheless, the problem of inadequate sanitation the world over, and in Sweet Home specifically, often does not get proper attention from politicians and pertinent organisations (Jewitt 2011:608).

The problem of human-waste disposal in Sweet Home Farm apparently coincides with the management history of the 4.In this context, cf. Plowright (2012) on the "ultimate untouchables' in India. 
community. One of the outstanding issues in this regard is the fact that the number of residents in this area has grown exponentially since the inception of the community in 1992 (Sacks 2012:4). This sudden escalation of residents in the restricted living area of Sweet Home is an important factor to take into account. There are so many informal dwellers that the limited toilet and sewage facilities are totally inadequate to meet their needs. If there were fewer residents, the problem would not have been so serious.

Whilst the sudden growth in numbers definitely exacerbated the situation, it would have been easier to handle and even to prevent the current situation if the sewage system had been effectively managed and extended. It is clear that Sweet Home must have had a long history of mismanagement. As we have seen, there has always been a shortage of toilets, and the available toilets are mostly of the unhygienic bucket or chemical type. Furthermore, the sewage canals are open.

The community has been trying for a long time to get private persons and institutions to meet their responsibility towards the residents of Sweet Home Farm, but to no avail. Their irritation reached a peak in 2011. Residents then turned to vandalist and violent demonstrations, burning toilets, breaking down traffic lights and blocking roads in an attempt to get the attention of the authorities (Sacks 2012:11-14). Even this failed, and the community still has to cope without a satisfactory sewerage system. Meanwhile the residents of Sweet Home Farm threaten to use even more drastic actions such as pouring out human excrement in public areas (as others have done before them - cf. Robins 2013).

On Thursday 01 August 2013, Siyamboleka James took The Cape Argus on a guided tour of the area. What they witnessed was dirty water up to the knees in some of the main streets. Footpaths could only be accessed by people wearing gumboots. According to Wilfred Solomons Johannes from Disaster Management, water reaching ankle height can already be classified as flooding, and in Sweet Home, conditions were even worse: the ground was completely saturated with water (Knoetze \& Du Plessis 2013).

Mulugeta et al. (2012:4) describe 'danger' as a phenomenon or human action that can lead to loss. By this definition, the circumstances in Sweet Home Farm are definitely dangerous and should not be taken lightly. Marelize Barnard (2013), a reporter at Die Burger, interviewed Patricia de Lille, mayor of Cape Town, and learned that several of the informal settlements around the mother city are situated in areas where the city council is legally not allowed to deliver services. According to Barnard (2013), De Lille explained that:

... the city council may not install flush toilets on land that is privately owned; in areas located directly underneath power cables; where there is overcrowding of residents; in environments within the flood line; or where there is no bulk infrastructure. (p. 6)
De Lille also alleges that $82 \%$ of informal settlements around Cape Town are located in areas where the city council is not allowed to deliver full municipal services. A political dimension is added to the problem when legislation actually restricts intervention.

Problems with proper sanitation seem to occur widely in the Western Cape. Currently 50 complaints in this regard have been lodged with the South African Human Rights Commission. eNews Channel Africa (eNCA) recently reported that, because of labour disputes, waste-removal contractors last emptied toilets in certain informal settlements around Cape Town 3 months ago. Frustration with the situation lead to employees of the organisation Sanicare participating in demonstrations by dumping human faeces on the N2. This action caused further trouble, and in the ensuing 'toilet war' (Breytenbach 2013:6) as Patricia de Lille dubbed it, residents showed their loathing for the current circumstances by again throwing human waste in public places. At the moment, 183 individuals are being prosecuted. They are charged with violating the Law on Environmental Protection.

The above-mentioned empirical reality of the plight of the shack dwellers in Sweet Home Farm proves that this is indeed a 'wicked problem'. It is therefore necessary to 'dive below the surface', so to speak, to try to understand the deeper causes of the sanitation problem.

\section{Head under the water - in search for clues}

The underwater search for reasons and motives underlying the sorry state of affairs in Sweet Home Farm is not a simple matter. There are several factors contributing to the wicked problem of dealing with the disposal of human waste. In this part of the article, attention is paid to these factors although the researcher is fully aware of the fact that he can only open up a few perspectives. Obviously, an inter-disciplinary approach is needed here. The issues and theories that will be highlighted should therefore be seen as an invitation to further discussion.

As was clear from our discussion thus far, the people of the Sweet Farm community are deeply frustrated concerning their sanitation problem. Therefore it could be a good idea to start from a physiological angle.

\section{Physiological factors}

Looking at Maslow's famous hierarchy or pyramid of human needs (Wikipedia n.d.), it is clear that the sanitation problems experienced by this community go against one of their basic rights, namely that their primary physiological needs - air, food, water, sleep and the management of human excreta - should be met. It is to be expected that people would be very unhappy and rebellious when their rights to these basic needs are denied. 


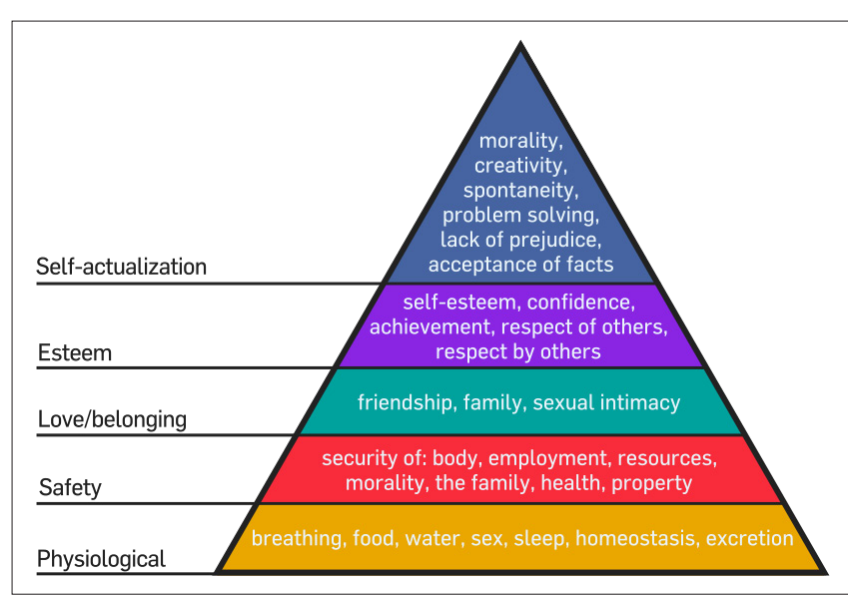

Source: Wikipedia, n.d., Maslow's hierarchy of needs, viewed 14 January 2014, from http:// upload.wikimedia.org/wikipedia/commons/thumb/6/60/Maslow\%27s_Hierarchy_of_ Needs.svg/450px-Maslow\%27s_Hierarchy_of_Needs.svg.png

FIGURE 1: Maslow's pyramid of basic human needs.

\section{Sociological factors}

Closely related to people's physiological needs are their sociological wants. The American sociologist James Davies' (1959) so-called Relative Deprivation Theory ${ }^{5}$ teaches us that a group of people who are convinced that their basic human rights are violated tend to join the ranks of those who share the same grievances. This collective unrest then forms the basis for extraordinary action, which often overflows into public protest against those responsible for the injustice. Gurr (1993:174), in his book Why men rebel, quotes the Relative Deprivation Theory and points to the phenomenon of the distribution of individual anger in society'. Gurr (1993:174) goes on to remind us how the communal grievances of a social group determine their inclination towards protest and rebellion. He concludes that 'communal grievances have a greater effect on mobilisation than any variable besides lost autonomy'.

The Relative Deprivation Theory explains some of the reasons underlying the protests launched by residents in Sweet Home Farm. They were well aware that they did not receive the same basic services as their neighbouring communities. Moreover, their pleas to the local government and leadership to rectify these conditions fell on deaf ears. It was this feeling of utter hopelessness that resulted in the community's decision to rise from a position of violated human dignity and despair to violent protest (Swart 2013:5).

\section{Political factors}

The political theory used by Meyer and Minkhoff (2004:1457) illustrates that specific political contexts can stimulate the forming of social movements. A case in point is the political climate in the Western Cape, characterised by the growing power in the hands of political decision-makers. Continual conflict between the ruling elite and polarisation in the

5.Davies (1959:283) popularised the theory of Relative Deprivation (also known as the Davies J-curve). According to this theory, frustration and discontent arise when individuals (or a group) had nurtured certain expectations of what should happen and these expectations then failed to realise. When a sudden downward curve is and these expectations then failed to realise. When a sudden downward curve is
experienced and the gap between expectations and reality grows even larger, it often results in unrest and the potential for social instability. political spectrum as well as an on-going decline in effective management, public order and basic services aggravate the tendency towards collective unrest and eventually of protest actions.

It is no surprise that residents of Sweet Home Farm, heartily sick of empty promises and the way in which political leaders had turned their backs on the community, turned to organised demonstrations. Before 1994, under the political system of apartheid, the shack dwellers of Sweet Home Farm were politically exploited because the area was seen as an ANC stronghold (Sacks 2012:5). Between 1994 and 2011 the settlement was ruled by non-elected political leaders from both the ANC and the South African Communist Party (SACP) - a form of management that had political gain in mind rather than the betterment of the community (Sacks 2012:5). Today Sweet Home Farm is used by both the ANC and the Democratic Alliance (DA) as a political pawn in parliamentary debates whilst unfulfilled promises from different parties are still being made to this community.

\section{Economic factors}

In his book A history of inequality in South Africa 1652-2002, Sampie Terreblanche (2002) discusses the theory of 'systematic exploitation and systematic exclusion'. With his theory, Terreblanche indicates that the 1994 change in the South African government might have brought about a shift in political power but not in economic power. Whilst the country and its workers were exploited during colonial rule, the dispensation of 1994 created false expectations of the new democratic and capitalistic economical system. This system did not result in a better life for the poor, but rather excluded them from the process of economic development (Terreblanche 2002:12).

The power shift from apartheid to a democratic capitalistic dispensation caused the failure of the system as such. In this kind of economic regime, democracy crumbles at the local level because the larger system allows the poor to be further exploited by the rich elite. In the end, this results in an unequal society (Alexander 2010:37).

In Terreblanche's newest publication, Lost in transformation, he once again gives an honest and extremely critical overview of the current state of political and economic affairs as well as socioeconomic development in South Africa. He writes:

It would not be an overstatement to claim that, from an organisational and a moral point of view, the South African dual political-economic system is in a very unhealthy state. (Terreblanche 2012:88)

This theory of Terreblanche has a direct bearing on the situation in Sweet Home Farm where the highly politicised elite are being enriched by the exploitation of the poorer residents - which aggravates their situation (Swart 2013:7).

Poverty is, of course, a universal phenomenon, and one specific economical system cannot take all the blame for it. 
However, it cannot be denied that neo-liberal capitalism exacerbates the poverty of certain groups of people, which would not have been the case if an alternative economic system had been implemented (cf. Terreblanche 2002:455 on social-democratic capitalism). Neo-liberal capitalism is characterised by the deregulation and liberalisation of markets - in other words, the normal rules that govern the activities of persons and companies are not observed (Duchrow 2003:28). Consequently, those with money (or in charge of money) are put into a position of maximum power and financial freedom whilst great numbers of poorer people are systemically excluded from the benefits brought about by money and other forms of financial protection mechanisms (Boesak, Weusmann \& Amjad-Ali 2005:37-40).

\section{Conclusion}

The physiological, sociological, political and economic factors and theories that had been discussed thus far, give us a clearer understanding of the situation in Sweet Home Farm. The indication is that a history of economic and political exploitation as well as underlying psychological and social factors played a role in the self-definition of the residents of this settlement. These complex situations caused a deterioration in the living conditions of the people in this settlement whilst they continue witnessing how others in neighbouring settlements do better and have more success. Their specific complaints regarding the management of human waste in their community seemed to have no impact except for empty promises from various sources that the problem will be alleviated - promises that were never fulfilled. In the end, emotions ran so high that they culminated in public demonstrations of protest.

\section{A theology of human waste?}

In Swart's (2013) recent contribution, South Africa's service delivery crisis: From contextual understanding to diaconal response, he offers a scientific and theological perspective on the service-delivery crisis in South Africa, which bears directly on the dire situation in Sweet Home Farm. Swart even goes so far as to say that this specific challenge can influence the nature of the study of practical theology. He calls this challenge 'an essential newness in the topical focus on the service-delivery crisis for South African practicaltheological scholarship' (Swart 2013:3). What he proposes is that practical theologians should creatively, and even by means of new modi, become involved in theological reflection on this matter. In the rest of this article, some theological perspectives on the challenge of human waste will come under the spotlight.

In recent times, we have seen a further development in the South African theological landscape, namely 'public theology ${ }^{6}{ }^{6}$ Koopman (2010) is of the opinion that, although it does have a specific and unique accent, public theology, in so far as it is contextual, should not be seen as something 6.Cf. the Beyers Naude Centrum for Public Theology at the Faculty of Theology of the University of Stellenbosch. totally different or removed from other theological trends such as prophetic or liberation theology. He writes: 'Public theology does not aim to replace the various contextual and liberation theologies but rather drink from their rich wells' Koopman (2010:134). In the same article, Koopman ponders on a few contours necessary for the development of a public theology. He names different approaches to public theology and describes the intradisciplinary, interdisciplinary and transdisciplinary nature of these approaches. Furthermore he points out how public theology is growing throughout the world. In his typically rhetorical way, Dirkie Smit (2011:5) responds by asking: 'Must something be called public theology in order to be public theology?' From this it is clear that the term 'public theology' is multifaceted and cannot be defined easily. However, different opinions agree on one point: There is a close relationship between church and theology, on the one hand, and public life and communities, on the other. The construct 'public theology' helps us to make sense of this relationship.

Within the South African context, the practical theologian Denise Ackermann (2005) articulated the 'public nature' of practical theology as follows:

... [P]ublic theology as public practical theology not only affirms the public character of all theology but points to the fact that theology lives in the tension between theory and praxis, between what we believe and what we do about what we believe. Public practical theology is done in service of the reign of God and comes out of a critical consciousness informed by social analysis, a concern for justice, the creative use of human imagination, and the willingness to risk actions that express our hope for a better world. (p. 69)

Some of the concepts used by Ackermann invite normative reflection in regard to the challenge of human-waste management. The 'critical consciousness informed by social analysis' that she speaks of cannot but cultivate a conscience that is sensitive to social justice. And, as she says, if the human imagination can be strengthened by the willingness to risk actions on behalf of others, it will be an expression of our hope for a better world.

As part of our normative reflection, we should realise that the problem of inadequate sanitation is closely linked to a disregard for basic human rights. The Johannesburg declaration on Sustainable Development, ${ }^{7}$ approved by the World Summit of Sustainable Development, committed themselves as early as 2002 to promote human dignity by providing sanitation. Rule 18 of this document reads:

We welcome the focus of the Johannesburg Summit on the indivisibility of human dignity and are resolved ... to speedily increase access to such basic requirements as clean water, sanitation ... (UN Documents 2002:2)

The Millennium Development Goals (n.d.) (goal 7, target 10) also undertakes to diminish by $50 \%$ the number of people living without sustainable access to safe water and 7.cf. UN Documents (2002). 
basic sanitation. The reason why sanitation receives such a prominent focus is because it is essential for the realisation of human rights. Where there is no functional system for the disposal of human waste, it can lead to serious health hazards and the spread of infectious diseases. This obviously has deep theological meaning and implications. When human rights and dignity are violated, the image of God (Imago Dei) is affected too. This brings to mind what Dietrich Bonhoeffer (2010) said during a speech in Barcelona in 1929:

The earth remains our mother, just as God remains our father, and our mother will only lay in the father's arms those who remain true to her ... bodily existence. (p. 43)

\section{Keeping head above water - the role of leadership}

In previous sections of this article, we tried to ascertain the underlying motifs, reasons and other contributing factors that caused the residents of Sweet Home Farm to live in such appalling circumstances, with human waste overflowing the streets. We also looked at some theological perspectives that can help us to develop a normative framework with which to deal with the challenge of human waste.

In this section, we turn our attention to practicalities and look at the role that leaders (also religious leaders) can play in communities like these. In this regard, one must once again bear in mind that we are dealing with a 'wicked problem' here. ${ }^{8}$ To merely expect churches, for instance, to launch a toilet-building project would not be taking into account the complexity of the problem. The role of Christian leadership demands a much more nuanced practical-theological approach. In this regard, Storrar (2013:2) warns that social challenges of this kind require creative actions that also emerge from the community itself. These social changes he describes as: 'complex research models of theological reflection and public religious praxis', which can benefit from local knowledge but also from expertise coming from outside (Storrar 2013:2).

In looking for creative actions to address the problem of human waste and expecting leadership to take the necessary action between what we discovered as the real and the ideal, the six different forms of the church that Smit (2004) refers to can be a good starting point. It also helps us to understand that it is possible to develop different types of leadership within each of these forms and therefore to take account of the complexity of the problem.

Smit's distinctive forms start with the church in prayer and worship because the way Christians approach everyday life and all of its challenges are from a relationship with God. In prayer and worship, we bring our deepest desires, complaints and gratitude to God, reflecting the needs in our lives. According to Smit (2004:352), we already experience a foretaste of the new reality that God provides, and we can cling to the promises of God as we become more aware of 8.Cf. Introduction to this article for more on this term. the world's needs. Through prayer, we become aware of our own needs in terms of poor sanitation, poverty, indignity and insecurity, but we also become aware of the needs of others (Smit 2004:353). One way of showing our compassion for the people living in these appalling conditions is through our prayer life. Leadership in the person of the liturgist and preacher can play an important part in bringing the problem to the attention of the members of the different congregations in and around Sweet Home Farm.

Secondly, we are part of congregations as living communities operating as living bodies that work to relieve the suffering of others (Smit 2004:354). Therefore, we as a church community take it upon ourselves to care for the needy. Leadership in the persons of the chairperson, the board members and the committee involved with charity and outreach can play an important role in this regard. Therefore churches and their members can decide to make children aware of the importance of personal hygiene and teach them the basic guidelines regarding human waste. The World Bank's Water and Sanitation Program, launched in April 2012, offers useful information on how sanitation could be improved in informal settlements. Even Worldwide Handwashing Day (15 October) ought to be celebrated in churches and schools annually.

That many of these initiatives are not yet realised in faith communities and that much still needs to be done is clear from the words of Siyamboleka James, a community leader from Sweet Home Farm: 'We have been forgotten ... by the government and by the churches - even the churches within Sweet Home Farms didn't participate to make a change' (Meija 2013:1).

The role of communities of faith links with the third aspect, namely that we need not tackle the task alone. Faith communities are also part of bigger bodies like circuits and Synods where we join efforts in addressing these challenges. Congregations are not supposed to be self-centred in their existence but are in relationships with one another because, through these networks of relations, we affirm our Godgiven value to each other, and together we can fight injustice and poverty (Smit 2004:355). As we saw in the discussion, the effects and reasons for the challenge of human waste, poverty, human dignity and security are complex issues that we cannot tackle on our own. Leadership through these bodies, their chairpersons and activities can make a huge contribution to the complex challenges.

This brings us to the fourth aspect, namely that we are also embedded in various other networks of Christian commitments, and therefore, we can stand together against a challenge like tackling the problem of a polluted context (Smit 2004:357). If we are serious about the unity of the Christian faith as it is confessed in church, there are various opportunities to express this unity by way of koinonia. It also provides the opportunity to become involved in the ministry of reconciliation where leaders of different faith communities 
can act as facilitators between the community and local government or political leaders.

Churches should not only join hands mutually but should also work together with Christian organisations and NGOs to help the people of Sweet Home Farm. Only through cooperation between churches and other organisations will they be able to master serious problems such as poverty and sanitation issues. Churches could, for instance, encourage their members to become involved with Habitat for Humanity, an organisation that establishes facilities in informal settlements, and with The Warehouse, a network organisation that also gives assistance to residents of informal dwellings. Breadline Africa is another NGO who has given support to Sweet Home residents. To acquire the needed resources and consultation to approach these problems effectively, churches can furthermore build relationships with organisations like Shack Dwellers International (SDI), Community Organisation Resource Centre (CORC) and Orchard Africa.

Fifthly, it also means that each individual will take responsibility in practical ways to contribute to the processes of service delivery (Smit 2004:358). The late Steve de Gruchy wrote an article 'Of agency, assets and appreciation: Seeking some commonalities between theology and development' (De Gruchy 2003:26-30), in which he pointed out that people living in poverty should themselves be agents of transformation, role players in their own development. When James 2:26 states that faith apart from works is dead, many people interpret these words as meaning that rich people should care for the poor. In reaction to this, De Gruchy (2003:29) argues that people living in poverty must themselves do something to alter their living circumstances. And other people wanting to help should not ask: 'What can we do for you?', but rather: 'How can we do it alongside you?'

The sixth and final aspect relates to the fact that the community of Sweet Home Farm is part of civil society and that part of our calling as a church involves the way we address the problem of society, how we show compassion and how we are all working together to build a better society (Smit 2004:360). God's solidarity with the victims of injustice is a confirmation of lives that can and will be renewed. This solidarity overcomes the helplessness of poverty, indignity and poor service delivery. Our participation as individual members in the activities of civil society, serving on the committees and boards, is a way of exercising leadership as service to the community.

The National Planning Commission, in their introduction to The National Development Plan, proposes a new approach to development, one which completely supports the idea of participating in the activities of civil society. The plan (National Development Plan 2011) is described as:

... one that moves from a passive citizenry receiving services from the state to one that systematically includes the socially and economically excluded, where people are active champions of their own development, and where government works effectively to develop people's capabilities to lead the lives they desire. (pp. 1-2)

This means that, when new projects are initiated, as happened when the Cape Town City Council started cleaning toilets in settlements on 26 April 2013, all the residents should be notified beforehand and also be encouraged to take part in the job. When initiatives are managed in this way, residents are mobilised not to see themselves as victims of their circumstances.

When starting a new project, it is wise to begin with a socalled 'appreciative inquiry' process into the assets already available in a particular community. An analysis of the Sweet Home settlement revealed that the following assets are available: quite a few members of the community were already actively involved in trying to improve the settlement. We also saw that Sweet Home does have an impartial community committee who succeeded in getting a number of different political factions to work together for the mutual goal of development. Furthermore we came to the conclusion that the settlement offered ample job opportunities and that several informal economical and entrepreneurial activities already exist in Sweet Home Farm.

\section{Conclusion}

The role of Christian leadership in Sweet Home Farm, namely to help the residents 'keep their heads above water', as the saying goes, is no simplistic matter but not without a hopeful side either. It will take courage and bravery, the willingness to listen to each other and to make use of social analyses like that of Sacks (2012). It will demand time, energy, sacrifice and the readiness of all stakeholders to work together for a greater purpose than individual interests. What happens in one community on the Cape Flats can help to solve problems in thousands of similar settlements. This study is an attempt to contribute to this endeavour.

It is perhaps fitting, so soon after Mr Mandela's demise, to heed his words from $1993^{9}$ about South Africa's transition to a democracy:

We do not want freedom without bread nor do we want bread without freedom. Therefore it is indicative to provide for all the fundamental rights and freedoms associated with a democratic society. (p. 1)

If we replace bread with sanitation, the point becomes clear. In this light, it is also quite evident that many of the factors contributing to the unfortunate situation regarding human waste in Sweet Home Farm could have been prevented if the appropriate legal steps had been taken - because the

9.Address of Nelson Mandela at his Investiture as Doctor of Laws. 01 August 1993, Soochow University, Taiwan. Available online from http://www.anc.org.za/show. php?id=4094 
South African constitution guarantees and protects the fundamental human rights of all its citizens. ${ }^{10}$

\section{Acknowledgements Competing interests}

The author declares that he has no financial or personal relationship(s) that may have inappropriately influenced him in writing this article.

\section{References}

Ackermann, D.M., 2005, 'Beyers Naudé: Public theologian', in L.D. Hansen (ed.), The legacy of Beyers Naudé, pp. 63-76, SUN Press, Stellenbosch.

African National Congress (ANC), 1993, Address of Nelson Mandela at his Investiture as Doctor of Laws, viewed, no date, from http://www.anc.org.za/show.php?id=4094

Alexander, P., 2010, 'Rebellion of the poor: South Africa's service delivery protests - A preliminary analysis', Review of African Political Economy 37(123), 25-40. http:// preliminary analysis', Review of African Politi
dx.doi.org/10.1080/03056241003637870

Barnard, M., 2013, 'Polisie beskerm toiletskoonmakers: Werkers al voorheen met geweld Gedreig', Die Burger, 12 Junie, besigtig 06 November 2013, by http:// www.dieburger.com/nuus/2013-06-12-polisie-beskerm-toiletskoonmakers

Boesak, A., Weusmann, J. \& Amjad-Ali, C. (eds.), 2005, Dreaming a different world: Globalization and justice for humanity and the earth: The challenge of the Accra Confession for the churches, SUN Media, Stellenbosch.

Bonhoeffer, D., 2010, Letters and papers from prison: Dietrich Bonhoeffer works, Augsburg Fortress, Minneapolis.

Breytenbach, J., 2013, 'Sake teen 183 weer uitgestel', Die Burger, 26 Oktober, besigtig 06 November 2013, by http://www.dieburger.com/nuus/2013-10-26-sake-teen183-weer-uitgestel

City of Cape Town, n.d., 'Water and sanitation services standard', Preliminary draft 2, March 2008, https://www.capetown.gov.za/en/Water/Documents/Water\%20 and\%20Sanitation\%20Service\%20Standards.pdf

Davies, J., 1959, 'A formal interpretation of the theory of relative deprivation', Sociometry 22(4), 280-296. http://dx.doi.org/10.2307/2786046

De Gruchy, S., 2003, 'Of agency, assets and appreciation: Seeking some commonalitiesbetween theology and development', Journal of Theology for Southern Africa 117, 20-39.

Duchrow, U., 2003, 'The economic state we're in: Can the economy work for everyone?', Studies in Christian Ethics 15(2), 25-44. http://dx.doi. org/10.1177/095394680201500204

eNCA, n.d., viewed 06 November 2013, from http://www.enca.com/south-africa/ sanitation-probe-western-cape

Fisher, S., 2012, 'Daycare centre gets toilet', Eye Witness News, viewed 06 November 2013, from http://ewn.co.za/2012/11/19/Kids-get-access-to-proper-sanitation

Gurr, T.R., 1993, Why men rebel, Princeton University Press, Princeton.

10.The Introduction to the Constitution describes our new community as one based on democratic values, social justice and fundamental human rights. If the Cape Town City Council used the correct legal procedures available to them, they could have protected the rights of the people who came to settle in Sweet Home Farm. If the residents had been informed about their rights, and had they been provided with the necessary legal aid, their grievances could have been settled in court, rather than taking the law into their own hands and resorting to violence - for which they had to pay a high price.
Jewitt, S., 2011, 'Geographies of shit:Spatial and temporal variations in attitudestowards human waste', Progress in Human Geography 35(5), 608-626. http://dx.doi.org/ 10.1177/0309132510394704

Knoetze, D. \& Du Plessis, H., 2013, 'Cape nearly knee-deep in rain water', IOL News, 15 August, viewed 06 November 2013, from http://www.iol.co.za/news/ south-africa/western-cape/cape-nearly-knee-deep-in-rain-water-1.1562900\#. Unnu2vnsR8E

Koopman, N.N., 2010, 'Some contours for public theology in South Africa', International Journal of Practical Theology 14(1), 123-139. http://dx.doi. org/10.1515/ijpt.2010.9

Krog, A., 2003, A change of tongue, Random House, Struik, Cape Town.

Kundera, M., 1984, The unbearable lightness of being, Faber \& Faber, London.

Mejia, L., 2013, 'I don't want to walk this journey alone...', interview with Siyamboleka James, viewed 07 November 2013, from http://www.micahchallenge.org. $\mathrm{za} / \mathrm{p}=607$

Meyer, D.S. \& Minkhoff, D.C., 2004, 'Conceptualising political opportunity', Socia Forces 84(4), 1457-1492. http://dx.doi.org/10.1353/sof.2004.0082

Mulugeta, G., Ayonghe, S., Daby, D., Dube, O.P., Gudyanga, F., Lucio, F. et al., 2012, 'Natural and human-induced hazards and disasters in sub-Saharan Africa', International Council for Science, science plan approved by the ICSU Regional Committee for Africa, 05-06 March 2007, Seychelles, viewed Regional Committee for Africa, 05-06 March 2007, Seychelles, viewed
12 November 2013, from http://www.icsu.org/africa/publications/reports-andreviews/icsu-roa-science-plan-on-hazards-disasters/

National Development Plan: Vision for 2030, 2011, NPC Online, viewed 06 November 2013, www.npconline.co.za

Plowright, A., 2012, New law to ban India's 'untouchable' toilet cleaners, viewed 07 November 2013, from http://www.google.com/hostednews/ afp/article/ALeqM5jEpYTU1WVVgV01AWsWKJVxge3ZFA?docld=CNG. cda5c6eed46de2d9a877d450fe906620661

Robins, S., 2013, 'How poo became a political issue', Daily News, 03 July, viewed 06 November 2013, from http://www.iol.co.za/dailynews/opinion/how-poobecame-a-political-issue-1.1541126\#.UnoSGicy1QJ

Sacks, J., 2012, 'Sweet home report: An investigation into the socio-political character of recent road blockades by protesting shackdwellers', research report for the Mail \& Guardian, 20 September, viewed 06 November 2013, from http://cdn. mg.co.za/content/document/2012/09/19/Sweet_Home_Final.pdf

Smit, D.J., 2004, 'Oor die kerk en maatskaplike uitdagings in ons land', Dutch Reformed Thelogical Journal 45, 350-362.

Smit, D.J. 2011, 'The paradigm of Public Theology - Origins and development', unpublished paper.

Storrar, W.F., 2013, 'Religion and an activistic civil society?: A challenge for public theology', paper, delivered at the Faculty of Theology, University of Stellenbosch, 26 February.

Swart, I., 2013, 'South Africa's service-delivery crisis: From contextual understanding to diaconal response', HTS Teologiese Studies/Theological Studies 69(2), Art. \#1996, 16 pages. http://dx.doi.org/10.4102/hts.v69i2.1996

Terreblanche, S.J., 2002, A history of inequality in South Africa 1652-2002, University of Natal Press, Scottsville.

Terreblanche, S.J., 2012, Lost in Transformation, KMM Review Publishing Company, Johannesburg.

The Millennium Development Goals, n.d., viewed 06 November 2013, from http:// www.un.org/millenniumgoals/environ.shtml

UN Documents: World Summit on Sustainable Development, 2002, Johannesburg Declaration on Sustainable Development, viewed 06 November 2013, from http:// www.un-documents.net/jburgdec.htm

WaterAid, 2013, viewed 06 November 2013, from http://www.wateraid.org/uk/whatwe-do/our-approach/research-and-publications

Wikipedia, n.d., Maslow's hierarchy of needs, viewed 14 January 2014, from http:// upload wikimedia org/wikipedia/commons/thumb/6/60/Maslow\%27s Hierarchy_of_Needs.svg/450px-Maslow\%27s_Hierarchy_of_Needs.svg.png 